\title{
A Longitudinal Analysis of the Cognitive Function and Related Factors in Older Adults Using a Multilevel Growth Model
}

\author{
Eunha Jo, Jee Eun Sung, Youngmee Lee \\ Department of Communication Disorders, Ewha Womans University, Seoul, Korea
}

Correspondence: Youngmee Lee, $\mathrm{PhD}$ Department of Communication Disorders, Ewha Womans University, 52 Ewhayeodae-gil, Seodaemun-gu, Seoul 03760, Korea

Tel: $+82-2-3277-4603$

Fax: +82-2-3277-2122

E-mail: youngmee@ewha.ac.kr

Received: May 4, 2021

Revised: August 2, 2021

Accepted: August 2, 2021

This work was supported by the Ewha Womans University Research Grant of 2021.
Objectives: The purpose of this study is to examine changes in the cognitive function of the elderly over time and to identify factors affecting the cognitive decline by dividing them into multidimensional factors such as socio-demographic factors, physical and mental health factors, hearing factors, and social contact factors. Methods: This study used the Korean Longitudinal Study of Aging (KLoSA). A multilevel growth model analysis was conducted on 992 elderly people aged 60 or older who had been measured repeatedly seven times from 2006 to 2018. Results: First, the results showed that the cognitive function of the elderly decreased linearly over the years. Second, the initial status of cognitive function decreased as the age increased and as education level and economic condition decreased. The change rate of the cognitive function increased as education level increased. Third, at each time point, depression level had a negative effect on cognitive function, and subjective hearing condition had a negative effect on cognitive function. These influences decreased over time. Conclusion: The lower the education level, the higher the depression level; and the worse the subjective hearing condition, the more likely the elderly are to experience cognitive decline. Because the impact on cognitive function is large in the early stages of depression and hearing loss, it is necessary to detect them early and to make appropriate intervention to prevent cognitive decline.

Keywords: Korean Longitudinal Study of Aging (KLoSA), Multilevel growth model, Aging, Cognitive function, Subjective hearing loss
급격한 고령화와 함께 대표적인 노인 질환 중 하나인 치매 환자 의 수가 증가하는 추세이며, 2018년 만 65세 이상 노인인구 중 치매 환자의 수는 약 75 만명, 치매 유병률은 $10.16 \%$ 에 이른다(National Institute of Dementia, 2019). 국립 중앙치매센터(2019)에서는 향후 치매 환자의 수를 2024년에는 1백만명, 2050년에는 3백만명으로 추정하고 있다. 정신장애진단 및 통계편람 제4판(Diagnostic and Statistical Manual of Mental Disorder-4th, DSM-VI)의 진단 기준 에 의하면, 치매는 기억장애와 더불어 실어증, 실행증, 실인증 혹은 실행기능의 손상 중 최소 한 가지 이상이 동반되는 복합적인 인지 결함장애로 정의되고 있다. 그러나 정상적인 노화 과정에서도 인지 기능 감퇴가 관찰되며(Light, 1991), 정상적 노화와 치매의 중간 단 계인 경도인지장애(mild cognitive impairment, $\mathrm{MCI}$ ), 치매에 이르
기까지 중증도에 따라 인지기능 감퇴의 범위가 다양하다(BaharFuchs, Clare, \& Woods, 2013). 따라서 인지기능 감퇴를 경험하는 노인인구는 앞서 보고된 치매 환자의 수를 훨씬 웃돌 것으로 예상 된다. 여러 선행연구에서 정상적인 노화 과정의 인지기능 감퇴가 치 매로 진행되기 전에 예방하는 것이 중요함을 보고하고 있다(Brookmeyer, Gray, \& Kawas, 1998; Kown, 2018; Lee et al., 2009; Sloane et al., 2002). Brookmeyer 등(1998)은 치매의 발병 시점을 2년 늦출 경 우 약 200 만명, 1 년을 늦출 경우 약 80 만명의 치매 환자가 발생하는 것을 예방할 수 있다고 예측하였으며, Sloane 등(2002)도 치매 환자 의 수를 감소시키는데 예방의 효과가 큼을 보고하고 있다. 또한 Lee 등(2009)은 체계적 고찰(systematic review)을 통해 노년층의 인지 기능 감퇴와 치매에 영향을 미치는 요인을 정리하고 이를 바탕으로 
인지기능 증진을 위한 수칙을 제시하고자 하였다. 이처럼 치매를 예방하기 위한 효과적인 방안을 마련하기 위하여 노년층의 인지기 능 감퇴에 영향을 미치는 요인을 확인하는 것이 필요하다.

노인인구의 지속적인 증가로 국내 인구 구조가 변화되는 것을 고 려할 때, 인지기능 감퇴를 경험하는 노인인구의 수는 더욱 증가할 것으로 예측할 수 있다. 이러한 양상을 반영하듯이, 국내외에서는 노년층의 인지기능에 관한 연구가 지속적으로 진행되고 있다. 예를 들면, Sung과 Kwag (2012) 그리고 Klencklen, Lavenex, Brandner와 Lavenex (2017)는 청년과 노인 집단을 대상으로 언어 및 작업기억 과제를 실시하여 노화에 따른 인지기능 감퇴를 확인하였다. 나아가 인지 저하를 경험하는 노년층(예: 경도인지장애, 알츠하이머 등)을 대상으로 언어 과제를 비롯하여 기억 및 주의력 등 집행기능과 관 련된 과제를 실시하여 노년층의 인지기능 감퇴 양상을 살펴보았다 (Choi, Sung, \& Jeong, 2020; Valech et al., 2018). 선행 연구(Choi et al., 2020; Klencklen et al., 2017; Sung \& Kwag, 2012; Valech, et al., 2018) 에서도 노화로 인한 인지기능 감퇴에 대한 연구결과는 일관적이다. 그러나 노화로 인한 인지기능 감퇴는 정체되어 나타나는 현상이 아 니며 점진적으로 변화하는 양상을 띄기 때문에 종단적 자료 분석 을 통하여 노화로 인한 인지기능 감퇴가 시간의 흐름에 따라 어떠 한 변화 양상을 보이는지 살펴볼 필요가 있다. Hayden 등(2011)은 코호트(cohort) 자료분석을 통하여 약 1,000 명의 정상 노인의 인지 기능 변화 양상을 살펴보았으며, 정상 노인을 인지기능 감퇴 속도에 따라 느린 감퇴 집단, 보통 감퇴 집단, 빠른 감퇴 집단으로 구분하였 다. 또한 Chodosh, Miller-Martinez, Aneshensel, Wight와 Karlamangla (2010) 그리고 Zaninotto, Batty, Allerhand와 Deary (2018)는 정상 노인을 대상으로 시간의 흐름에 따른 인지기능의 변화율을 확 인하였으며, 인지기능의 변화에 연령, 교육수준, 신체기능, 우울증 상 등의 요인이 미치는 영향력에 차이가 있음을 확인하였다. 여기서 주목할 점은 노년층 내에서도 개인의 특성에 따라 인지기능 감퇴 양상에 차이가 있다는 것이다. 이러한 측면을 고려하여, 많은 연구 자들이 노년층의 인지기능 저하에서 보이는 개인 간 차이와 관련된 요인에 관한 다양한 연구를 진행해오고 있다. 노년층의 인지기능과 관련된 요인들을 살펴본 연구는 크게 사회인구학적 요인, 신체적·정 신적 요인, 사회접촉 요인으로 나눠서 살펴볼 수 있다. 사회인구학 적 요인과 관련된 요인에는 연령, 교육수준, 경제상태가 해당되며, 연령과 교육수준은 노년층의 인지기능과 관련이 높은 요인으로 알 려져 있다(Kim, 2010; Kim, Kim, \& Kim, 2011; Kwon \& Paek, 2014; Won \& Kim, 2003). Lee, Kim, Lee, Chung과 Park (2012)이 청년, 중 년, 노인으로 구분된 세 연령 집단을 대상으로 인지기능을 살펴본 결과, 연령 증가에 따른 인지기능의 감소가 공통적으로 나타났었
다. 교육수준도 노년층의 인지기능에 영향을 미치는 주요 요인으로 (Kim, 2010; Kwon \& Paek, 2014; Won \& Kim, 2003), 교육은 건강한 삶을 도모하는 방식으로 생활을 영위하고 조절하는 데 필요한 자 원을 제공해 주며 연령이 증가할수록 그 영향력이 더욱 커지는 것 으로 알려져 있다(Mirowsky \& Ross, 2005). 또한, Jeon (2013)은 경 제적 소득이 높을수록 인지기능이 개선될 가능성이 높은 것으로 보고하고 있으며, Kim 등(2011)은 소득수준이 낮을수록 인지기능 저하의 위험이 유의미하게 증가함을 보여주고 있다.

노년층의 신체적·정신적인 건강상태 요인도 인지기능과 관련이 있으며, 특히 개인이 지각하는 주관적인 건강상태는 노화에 따른 손실을 보상하는 자원으로 여겨지고 있다(Steverink, Westerhof, Bode, \& Dittmann-Kohli, 2001). 주관적 건강은 인지기능과 정적 인 상관관계를 보이며(Seo \& So, 2016), 주관적 건강상태가 좋을수 록 노인의 인지기능이 높아지는 경향이 있다(Lee, 2014). 또한, 우울 증상은 인지기능의 저하와 치매의 위험요인으로 알려져 있으며 (Barnes et al., 2008; Lee \& Kang, 2011), Chodosh, Kado, Seeman과 Karlamangla (2007)는 7년간의 코호트(cohort) 자료분석을 통해 우울증상이 노년층의 인지기능 저하와 강하게 연관되어 있음을 보 고하였다. 그리고 노년층의 인지기능 감퇴에 영향을 미치는 요인으 로 청력 요인이 있다. 노인성 난청(presbycusis)은 노인인구에서 빈 번하게 관찰되는 질환으로, 최근 노화에 따른 감각기능의 변화가 인지기능에 미치는 영향에 주목하기 시작하면서 노인성 난청과 노 년층의 인지기능 저하 간의 관련성을 밝히고자 하는 연구가 다수 진행되었다. Lin 등(2011)은 정상 청력 성인과 난청 성인을 대상으 로 약 11 년 동안 추적한 결과, 정상 청력 성인보다 난청 성인이 치매 발병 확률이 높았으며 난청 중증도가 높아짐에 따라 치매 발병 위 험도가 증가함을 확인하였다. Lee (2018)는 장노년층을 대상으로 한 메타분석을 통하여 난청이 인지기능에 미치는 영향을 체계적이 며 종합적으로 살펴본 결과, 장노년층에서의 난청이 인지기능 저하 와 관련성이 있음을 확인하였다.

마지막으로 사회적인 접촉 요인도 노년층의 인지기능 감퇴에 영 향을 미치는 것으로 알려져 있다(Fratiglioni, Wang, Ericsson, May$\tan$ \& Winblad, 2000; Hwang \& Kwon, 2009; James, Wilson, Barnes, \& Bennett, 2011; Kim, 2015; Seeman et al. 2011; Ybarra et al., 2008). Fratiglioni 등(2000)은 혼자 생활하고 사회적 상호작용 빈도가 매 우 낮은 사람들은 3 년 후 치매가 나타날 가능성이 그렇지 않은 사람 들에 비해 2배가량 높다는 것을 확인하였다. 또한, Ybarra 등(2008) 은 사회적 접촉 빈도가 증가할수록 노인의 인지기능이 향상됨을 확인하였다. Hwang과 Kwon (2009)은 종교활동 및 여가활동과 같 은 사회활동 참여가 고령자의 인지기능에 유의미한 영향을 미치는 
것으로 보고하였다. 이처럼 노년층의 인지기능에 영향을 미치는 요 인을 살펴본 선행연구는 다양한 측면에서 이루어지고 있으며, 노년 층의 인지기능에 영향을 미치는 요인을 살펴보기 위해서 노년층의 인지기능 감퇴에 여러 요인이 복합적으로 작용할 수 있음을 고려해 야 할 필요가 있다.

국내 급속한 인구 구조 변화가 이루어짐에 따라 고령화 현상을 적절히 이해하고 이로 인한 사회적 문제에 대한 대책을 마련하는 것은 중요하다. 노년층의 인지 저하가 특정 시점에 급격하게 이루어 지기 보다는 장기간에 걸쳐서 진행되는 점을 고려할 때, 관련 요인 들이 장기간에 걸쳐서 미치는 영향을 분석할 필요가 있다. 하지만 노년층의 인지 저하와 관련된 요인을 탐색한 기존 연구들은 특정 지역과 연령대에 분포하는 대상자 선정, 일차적인 데이터 수집과 분석 등으로, 노년층의 인지 변화에 영향을 미치는 요인들의 다층 적인 분석에는 한계를 지니고 있다. 이를 보완하기 위해서는 노년층 의 신체적, 정신적, 경제적, 사회적 삶 전반에 걸친 포괄적인 자료의 분석이 필요하며, 횡단적인 자료 분석에서 그치는 것이 아니라 장기 적인 변화를 살펴볼 수 있는 종단적인 자료 분석이 필요하다. 종단적 자료는 동일한 개인을 여러 시점에 걸쳐 반복적으로 관찰하여 수 집되며, 여러 시점에 관찰된 반복측정치가 각 개인에 내재된(nested) 구조를 갖는다. 즉, 종단적 자료는 개인 수준과 각 개인이 반복 적으로 관찰되는 관찰시점 수준의 두 개의 수준을 갖는 다층자료 (multilevel data)이다. 관찰시점 수준의 변수인 반복측정치는 동일 한 개인을 반복 관찰하여 수집된 것이므로 각 개인 내에서 반복측 정치 간에 상호상관이 존재한다(Kang, 2016). 그러나 회귀분석이 나 분산분석모형 등과 같은 전통적인 통계모형은 단층자료를 분석 대상으로 하기 때문에, 전통적인 통계 모형을 적용하여 다층자료 를 분석한다면 연구결과는 타당성을 잃게 된다(Burstein, 1980; Cooley, Bond, \& Mao, 1981; Cronbach \& Webb, 1975; Kang, 2016). 따라서 노년층의 인지기능 변화와 관련된 요인들의 영향력을 종단 적으로 살펴보기 위하여 종단자료의 다층적인 구조를 반영하여 분석할 수 있는 다층성장모형(multilevel growth model)이 적용될 필요가 있다.

한국노동연구원의 고령화연구패널조사(Korean Longitudinal Study of Aging, KLoSA) 자료는 2006년 1차 조사를 실시하여 격년 주기로 지난 2018년 7차까지 조사가 진행되었으며, 제주도를 제외
한 전국 지역에 거주하는 만 45 세 이상 중고령자를 표본으로 하고 있다. 또한, 해당 자료에는 기본적인 인적 속성을 비롯한 건강상태, 경제상태, 사회적 활동 등 광범위한 정보를 포함하고 있어, 노년층 의 인지기능의 종단적인 변화를 살펴보고 관련된 요인의 영향을 살 펴보는데 적합하다고 할 수 있다. 국내에서 동일한 패널조사 자료 를 활용하여 노년층의 인지기능과 관련된 요인을 분석한 연구가 발 표된 바가 있었지만, 청력저하를 경험한 노년층의 자료만을 활용하 거나 특정 시점에서의 노년층의 인지기능만을 분석하였다(Han, 2018; Lee, 2016). 이에 따라 본 연구에서는 1차부터 7차까지의 고령 화연구패널조사(KLoSA) 자료를 사용하여 시간 흐름에 따른 노년 층의 인지기능의 변화를 살펴보고, 사회인구학적 요인, 신체적·정 신적인 건강상태 요인, 청력 요인, 사회적인 접촉 요인과 같은 다차 원적인 요인들이 시간 흐름에 따라 노년층의 인지기능 변화에 미치 는 영향을 살펴보고자 하였다.

\section{연구방법}

\section{연구대상}

본 연구는 한국노동연구원에서 실시한 고령화연구패널조사의 1 차부터 7 차까지의 자료를 사용하였다. 고령화연구패널조사는 2006년에 1차 조사가 실시되었으며, 이후 격년 주기로 조사가 진행 되어 2018년까지 7차에 걸친 추적조사가 완료되었다. 해당 조사는 제주도를 제외한 전국 지역에 거주하는 만 45세 이상 중고령자를 표본으로 하고 있으며, 기본적인 인적 속성을 비롯한 건강상태, 경 제상태, 사회적 활동 등 광범위한 범위에서 설문 내용이 구성되어 있다. 본 연구에서는 고령화연구패널 1차 조사에 참여한 총 조사 대상자 10,254 명 중에서 7차까지 추적이 이루어지고 주요변수에 결측치가 없는 만 60 세 이상 노년층 992 명을 분석 대상으로 하였다. 대상자 기본정보는 Table 1에 제시하였다.

\section{측정도구}

사회인구학적인 요인

사회인구학적인 요인에는 연령과 교육수준, 경제상태를 포함하 였다. 연령은 1 차 조사 당시의 연령을 사용하였다. 교육수준은 초등 학교 졸업 이하, 중학교 졸업, 고등학교 졸업, 대학교 졸업 이상으로

Table 1. Demographic information on participants

\begin{tabular}{llcc}
\hline & Age (yr) & $\begin{array}{c}\text { K-MMSE Score } \\
\text { (at the 1st survey) }\end{array}$ & $\begin{array}{c}\text { Education level (below elementary school: middle } \\
\text { school: high school: undergraduate or higher) }\end{array}$ \\
\hline Mean (SD, Range) & $66.05(4.69,60-85)$ & $26.01(3.80,10-30)$ & $544: 166: 202: 80$ \\
\hline
\end{tabular}


구분하였다. 경제상태는 대상자의 경제상태에 대한 만족도를 묻는 문항(“자신의 경제상태에 대해서는 어느 정도 만족하고 계십니 까?”)의 응답 결과를 사용하였다. 해당 문항에 대한 응답은 0점에 서 100 점까지 10 점 간격으로 구분되어 있었으며, 점수가 높을수록 만족도가 높음을 의미한다.

\section{신체적· 정신적 건강 요인}

신체적 · 정신적 건강 요인에는 주관적 건강상태와 우울수준을 포함하였다. 주관적 건강상태는 고령화연구패널의 문항 중 본인의 건강상태에서 대해 어떻게 생각하는지 묻는 문항(“본인의 건강상 태에 대해 어떻게 생각하십니까?”)을 이용하였다. 본 문항의 응답 은 '매우 좋음(1)', '좋음(2)', '보통(3)', '나쁨(4)', '매우 나쁨(5)'의 5점 리커트 척도로 구성되어 있으며, 점수가 높을수록 건강상태가 좋 음을 의미하도록 역코딩하였다. 우울수준은 고령화연구패널 문항 중 한국판 역학연구센터 우울 척도(Korean version of Center for Epidemiological Studies-Depression Scale, K-CES-D; Jeon, Choi, \& Yang, 2001)의 점수를 사용하였다. 고령화연구패널 조사에서 사 용한 K-CES-D의 문항은 총 10 개로 구성되어 있으며, 각 문항당 1 점으로 점수를 채점하도록 되어 있다. 총점은 10 점으로 점수가 높 을수록 우울증 정도가 심함을 의미한다.

\section{청각 요인}

청각 요인은 고령화연구패널의 문항 중 본인의 청력에 대해서 어 떻게 생각하는지 묻는 문항(“청력은 어떻습니까? 보청기를 사용하 시는 경우는 보청기를 낀 상태를 말씀해 주십시오.”)을 이용하여 주관적 청력상태를 측정하였다. 본 문항의 응답은 '매우 좋음(1)', '좋음(2)', ‘보통(3), '나쁨(4)', '매우 나쁨(5)'의 5점 리커트 척도로 구 성되어 있어서, 점수가 높을수록 청력상태가 좋음을 의미하도록 역코딩하였다.

\section{사회적 접촉 요인}

사회적 접촉 요인은 친한 사람들과 사회적 접촉 정도를 묻는 설 문 문항으로 측정하였다. 고령화연구패널의 문항 중 친구, 친척, 이

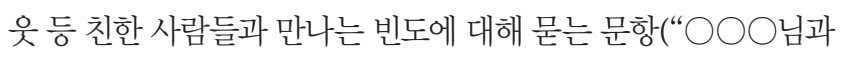
가까이에 살면서 친하게 지내는 친구나 친척 또는 이웃사촌이 있습 니까? 있으시다면 이분들과 얼마나 자주 만나십니까?)을 활용하였 으며, 응답은 '친하게 지내는 사람 없음(1)'부터 거의 매일 만남(10)' 까지 1 점부터 10 점까지 10 점 척도로 구성되어 있었다. 점수가 높을 수록 접촉 빈도가 높도록 재코딩하였다.

\section{인지기능}

종속변수인 인지기능은 한국판 간이정신상태검사(Korean version of Mini-Mental State Examination, K-MMSE; Kang, 2006)의 점수를 사용하였다. K-MMSE는 지남력, 기억등록 및 회상, 주의집 중 및 계산, 언어능력 등에 대한 문항으로 구성되어 있다. 해당 검사 의 총점은 30 점으로, 점수가 낮을수록 인지기능이 저하됨을 의미 한다.

\section{자료분석}

본 연구에서는 시간의 흐름에 따른 노년층의 인지기능 변화와 이 러한 변화에 영향을 미치는 요인이 무엇인지 살펴보고자 하였으며, 1 차 조사에서 7 차 조사까지 7 개의 시점에 대해 반복 측정된 인지기 능 및 관련 변수들에 대한 각 시점의 측정치가 개인에 내재된(nested) 구조의 자료를 활용하였다. 다층성장모형(multilevel growth model)은 이와 같은 개인에 대한 측정치가 개인에 내재되는 두 개 의 수준으로 이루어진 자료 구조를 반영하여 개인의 변화를 분석 하는 데 적합한 것으로 알려져 있다(Raudenbush \& Bryk, 2002). 따라서 본 연구에서는 개인(2수준)과 개인에 내재된 시점 별 측정 치(1수준)의 두 개의 수준으로 이루어진 자료 구조를 반영한 2 수준 다층성장모형을 적용하여 분석하고자 한다. 1 수준에는 인지기능 의 변화 양상을 살펴보기 위하여 인지기능을 종속변수로 하여 측 정 시점과 신체적·정신적 건강 요인(건강상태, 우울수준), 청각 요인 (청력상태), 사회적 접촉 요인(사회적 접촉)을 투입하여 인지기능 및 인지기능에 영향을 미치는 요인의 변화 함수를 추정하였으며, 2수준에는 개인차를 설명하기 위한 변수로 사회인구학적인 요인 (연령, 교육연수, 경제상태)을 투입하여 변화의 개인차를 추정하였 다. 1 수준에는 측정 시점은 1 차 조사 시점을 기준으로, 1 차 조사부 터 7차 조사 시점을 $0,1,2,3,4,5,6$ 으로 중심화(centering)하였다. 그 외 변수는 각수준에서 전체평균중심화(grand mean centering) 하였다.

본 연구에서는 다음의 두 단계로 다층성장모형 분석을 실시하였 다. 먼저, 시점을 나타내는 변수를 제외한 1 수준과 2 수준의 모든 독 립변수를 투입하지 않은 무조건 모형(unconditional model)을 구 성하여 시간의 흐름에 따라 노년층의 인지기능이 어떻게 변화하는 지 알아보고자 하였다. 무조건 모형의 식은 다음과 같으며 이를 기 초모형으로 설정하였다.

1수준:

$$
\mathrm{Y}_{\mathrm{ti}}=\pi_{0 \mathrm{i}}+\pi_{\mathrm{li}}(\mathrm{TIME})_{\mathrm{ti}}+\mathrm{e}_{\mathrm{ti}}
$$

2수준:

$$
\pi_{0 \mathrm{i}}=\beta_{00}+\mathrm{r}_{0 \mathrm{i}}
$$


$\pi_{1 \mathrm{i}}=\beta_{10}+\mathrm{r}_{1 \mathrm{i}}$

위 식에서 $\mathrm{Y}_{\mathrm{ti}}$ 는 $\mathrm{t}$ 시점에서 측정된 대상 $\mathrm{i}$ 의 인지기능을 의미한다. $\pi_{0 \mathrm{i}}$ 는 1 차 조사 시점에서 측정된 대상 $\mathrm{i}$ 의 인지기능을 의미하며, $\pi_{1 \mathrm{i}}$ 는 대상 $\mathrm{i}$ 의 인지기능 변화율을 의미한다. $\mathrm{e}_{\mathrm{t} i}$ 는 $\mathrm{t}$ 시점에 대한 대상 $\mathrm{i}$ 의 오차를 의미한다. 또한 $\beta_{00}$ 과 $\beta_{10}$ 은 각각 개인별 인지기능의 초기 치 평균과 변화율 평균을 의미하며 고정효과(fixed effect)를 나타 낸다. $\mathrm{r}_{0 i}$ 와 $\mathrm{r}_{1 \mathrm{i}}$ 는 각각 인지기능의 초기치 평균의 개인차와 인지기능 의 변화율 평균의 개인차를 의미하며 무선효과(random effect)를 나타낸다.

다음으로, 조건 모형(conditional model)을 구성하여 인지기능 의 변화에 영향을 미치는 요인이 무엇인지 알아보고자 하였다. 이 때, 1 수준에 투입된 시간의존적 변수의 시간의존적 효과를 살펴보 기 위하여, 1 수준에 시간의존적 변수와 측정 시점의 상호작용항을 투입하여 분석을 실시하였다. 즉, 인지기능을 종속변수로 하여 1 수 준에 시간의존적 변수와 상호작용항, 2 수준에 개인차 설명 변수를 투입한 연구모형은 다음과 같다.

1수준:

$\mathrm{Y}_{\mathrm{ti}}=\pi_{0 \mathrm{i}}+\pi_{\mathrm{li}}(\mathrm{TIME})_{\mathrm{ti}}+\pi_{2 \mathrm{i}}$ (주관적 건강상태 $)_{\mathrm{ti}}+\pi_{3 \mathrm{i}}($ 우울

수준 $)_{\mathrm{ti}}+\pi_{4 \mathrm{i}}(\text { 주관적 청력상태 })_{\mathrm{ti}}+\pi_{5 \mathrm{i}}$ (사회적 접촉 $)_{\mathrm{ti}}+$

$\pi_{6 \mathrm{i}}\left(\text { 주관적 건강상태 }{ }^{*} \mathrm{TIME}\right)_{\mathrm{ti}}+\pi_{7 \mathrm{i}}\left(\text { 우울수준 }{ }^{*} \mathrm{TIME}\right)_{\mathrm{ti}}$

$+\pi_{8 \mathrm{i}}\left(\text { 주관적 청력상태 }{ }^{\mathrm{TIME}}\right)_{\mathrm{ti}}+\pi_{9 \mathrm{i}}$ (사회적 접촉 $\left.{ }^{\mathrm{TIME}}\right)_{\mathrm{ti}}$

$+e_{\mathrm{ti}}$

2수준:

$$
\begin{aligned}
& \pi_{0 \mathrm{i}}=\beta_{00}+\beta_{01} \text { (연령)i }+\beta_{02} \text { (교육수준)i+ } \beta_{03} \text { (경제상태) } \mathrm{i}+\mathrm{r}_{0 \mathrm{i}} \\
& \pi_{1 \mathrm{i}}=\beta_{10}+\beta_{11} \text { (연령) } \mathrm{i}+\beta_{12} \text { (교육수준) } \mathrm{i}+\beta_{13} \text { (경제상태) } \mathrm{i}+\mathrm{r}_{1 \mathrm{i}} \\
& \pi_{2 \mathrm{i}}=\beta_{20} \\
& \pi_{3 \mathrm{i}}=\beta_{30} \\
& \pi_{4 \mathrm{i}}=\beta_{40} \\
& \pi_{5 \mathrm{i}}=\beta_{50} \\
& \pi_{6 \mathrm{i}}=\beta_{60} \\
& \pi_{7 \mathrm{i}}=\beta_{70} \\
& \pi_{8 \mathrm{i}}=\beta_{80} \\
& \pi_{9 \mathrm{i}}=\beta_{90}
\end{aligned}
$$

위 식에서 $\pi_{0 \mathrm{i}}$ 와 $\pi_{1 \mathrm{i}}$ 는 각각 인지기능의 초기치와 변화율을 의미 한다. $\beta_{00}$ 과 $\beta_{10}$ 은 고정효과로서 각각 개인별 인지기능의 초기치 평 균과 변화율 평균을 의미하며, $\beta_{01}, \beta_{02}, \beta_{03}$ 은 각각 2수준 변수인 연 령, 교육수준, 경제상태의 주효과를 의미하고 $\beta_{11}, \beta_{12}, \beta_{13}$ 은 각각 연
령, 교육수준, 경제상태와 시점의 상호작용 효과를 의미한다. $\mathrm{r}_{0 \mathrm{i}}$ 와 $\mathrm{r}_{11}$ 는 무선효과로서 각각 인지기능의 초기치 평균의 개인차와 인지 기능의 변화율 평균의 개인차를 의미한다. 또한 $\beta_{20}, \beta_{30}, \beta_{40}, \beta_{50}$ 은 고정효과로서 각각 1 수준 변수인 주관적 건강상태, 우울수준, 주관 적 청력상태, 사회적 접촉의 주효과를 의미하며, $\beta_{60}, \beta_{70}, \beta_{80}, \beta_{90}$ 은 각각 건강상태, 우울수준, 주관적 청력상태, 사회적 접촉과 시점의 상호작용 효과를 의미한다.

결측치 처리는 가장 보편적인 결측 처리방법인 완전제거법(listwise deletion, $\mathrm{LD}$ )을 사용하여 하나의 사례라도 결측된 문항이 존 재할 경우 그 행의 전체 자료를 삭제하여 분석에서 제외하였다. 즉, 1 차 조사에서 7 차 조사까지 추적이 완료된 자료 중 주요변수에 결 측치가 없는 자료만을 분석 대상으로 하였다. 다층성장모형 분석 은 HLM 8.0 프로그램을 사용하였으며, 그 외 주요 변수에 대한 기 초적 분석은 SPSS 25.0 프로그램을 사용하였다.

\section{연구결과}

\section{주요 측정변수의 조사 시점 별 기술통계치}

주요 측정변수의 기술통계치를 Table 2에 제시하였다. 1 수준 변 수인 인지기능, 주관적 건강상태, 우울수준, 주관적 청력상태, 사회 적 접촉은 1 차 조사 시점부터 7 차 조사 시점까지 측정 시점별로 최 소값과 최대값, 평균, 표준편차를 제시하였으며, 2수준 변수인 연 령, 교육수준, 경제상태는 1 차 조사 시점의 최소값과 최대값, 평균, 표준편차를 제시하였다.

종속변수인 인지기능은 1 차 조사 시점의 평균이 $26.01,7$ 차 조사 시점의 평균이 23.51로, 전반적으로 시간의 흐름에 따라 감소하는 추세를 보였다. 1 수준에 투입된 시간의존적 변수의 경우, 주관적 건 강상태는 1 차 조사 시점의 평균이 $3.01,7$ 차 조사 시점의 평균이 2.70 으로 시간의 흐름에 따라 전반적으로 감소하였다. 우울수준은 1 차 조사 시점의 평균이 $2.79,7$ 차 조사 시점의 평균이 3.60 으로, 매 측정 시점마다 증가하는 양상을 보였다. 주관적 청각상태는 1 차 조 사 시점 평균이 $3.66,7$ 차 조사 시점 평균이 3.41 로 감소를 보였으나 측정 시점 간 평균의 차이가 두드러지지 않았다. 사회적 접촉은 1 차 조사 시점 평균이 $7.67,7$ 차 조사 시점 평균이 7.07로 2차 조사 시점 평균이 8.03 으로 1 차 조사 시점 평균에 비해 소폭 증가한 모습이나 2 차 조사 시점 이후 7 차 조사 시점까지 매 측정 시점마다 감소하는 양상을 보였다.

2수준 변수의 경우, 평균 연령은 66.05, 평균 교육수준은 1.82 , 평 균 경제상태는 49.79였다. 연령대 별 분포를 살펴보면, 총 992명 중 에 60대(77.72\%)가 771명, 70대(21.67\%)가 215명, 80대(.60\%)가 6명 
Table 2. Descriptive statistics of variables on participants

\begin{tabular}{|c|c|c|c|c|}
\hline & Min & Max & Mean & SD \\
\hline \multicolumn{5}{|l|}{ Dependent variable } \\
\hline \multicolumn{5}{|l|}{ Cognitive function ${ }^{\mathrm{a}}$} \\
\hline $1 \mathrm{st}$ & 10 & 30 & 26.01 & 3.80 \\
\hline 2nd & 4 & 30 & 25.49 & 4.05 \\
\hline $3 r d$ & 3 & 30 & 25.38 & 4.58 \\
\hline 4th & 2 & 30 & 25.26 & 4.85 \\
\hline 5th & 0 & 30 & 24.77 & 4.90 \\
\hline 6 th & 0 & 30 & 25.11 & 5.53 \\
\hline 7th & 0 & 30 & 23.51 & 5.98 \\
\hline \multicolumn{5}{|l|}{ 1-level } \\
\hline \multicolumn{5}{|c|}{ Subjective health condition ${ }^{b}$} \\
\hline $1 s t$ & 1 & 5 & 3.01 & .93 \\
\hline 2nd & 1 & 5 & 3.01 & .82 \\
\hline $3 r d$ & 1 & 5 & 2.91 & .82 \\
\hline 4th & 1 & 5 & 2.88 & .83 \\
\hline 5th & 1 & 5 & 2.77 & .82 \\
\hline 6th & 1 & 5 & 2.92 & .82 \\
\hline 7th & 1 & 5 & 2.70 & .81 \\
\hline \multicolumn{5}{|l|}{ Depression level $^{\mathrm{c}}$} \\
\hline $1 \mathrm{st}$ & 0 & 10 & 2.79 & 2.47 \\
\hline 2nd & 0 & 10 & 3.54 & 2.82 \\
\hline $3 r d$ & 0 & 10 & 3.59 & 2.94 \\
\hline 4th & 0 & 10 & 3.52 & 2.91 \\
\hline 5th & 0 & 10 & 3.10 & 2.71 \\
\hline 6th & 0 & 10 & 3.00 & 2.76 \\
\hline 7th & 0 & 10 & 3.60 & 2.95 \\
\hline \multicolumn{5}{|c|}{ Subjective hearing condition ${ }^{\mathrm{b}}$} \\
\hline $1 \mathrm{st}$ & 1 & 5 & 3.66 & .71 \\
\hline 2nd & 1 & 5 & 3.60 & .69 \\
\hline $3 r d$ & 1 & 5 & 3.51 & .70 \\
\hline 4th & 1 & 5 & 3.48 & .68 \\
\hline 5th & 1 & 5 & 3.34 & .74 \\
\hline 6 th & 1 & 5 & 3.29 & .76 \\
\hline 7th & 1 & 5 & 3.41 & .77 \\
\hline \multicolumn{5}{|l|}{ Social contract ${ }^{c}$} \\
\hline $1 s t$ & 1 & 10 & 7.67 & 2.81 \\
\hline 2nd & 1 & 10 & 8.03 & 2.20 \\
\hline $3 r d$ & 1 & 10 & 7.71 & 2.46 \\
\hline 4th & 1 & 10 & 7.82 & 2.43 \\
\hline 5th & 1 & 10 & 7.31 & 2.62 \\
\hline 6 th & 1 & 10 & 7.37 & 2.88 \\
\hline 7th & 1 & 10 & 7.07 & 2.98 \\
\hline \multicolumn{5}{|l|}{ 2-level } \\
\hline Age & 60 & 85 & 66.05 & 4.69 \\
\hline Education Level $^{d}$ & 1 & 4 & 1.82 & 1.02 \\
\hline Economic Condition ${ }^{e}$ & 0 & 100 & 49.78 & 22.67 \\
\hline
\end{tabular}

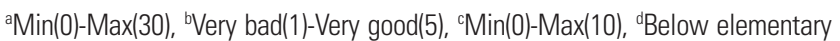
school(1)-Undergraduate or higher(4), ${ }^{e} \operatorname{Min}(0)-\operatorname{Max}(100)$.
으로 60 대가 가장 큰 비율을 차지하였으며, 교육수준 별 분포를 살 펴보면, 총 992명 중에 초등학교 졸업 이하(54.84\%)가 544명, 중학 교 졸업(16.73\%)이 166명, 고등학교 졸업(20.36\%)이 202명, 대학교 졸업 이상 $(8.06 \%)$ 이 80 명으로 초등학교 졸업 이하가 가장 큰 비율 을차지하였다.

\section{인지기능의 종단적 변화 분석}

시간의 흐름에 따른 노년층의 인지기능의 변화양상과 이에 따른 개인차를 추정하기 위하여 다른 변수를 투입하지 않은 무조건 모 형을 구성하여 기초모형 분석을 실시하였다(Table 3). 초기치와 변

Table 3. Results of the unconditional model analysis

\begin{tabular}{lccc}
\hline Fixed effect & Coefficient & SE & $t$ \\
\hline Initial status $\left(\beta_{00}\right)$ & $26.026^{* * *}$ & .118 & 220.344 \\
Rate of change $\left(\beta_{10}\right)$ & $-.317^{* * *}$ & .025 & -12.592 \\
\hline Random effect & Variance & SD & $\chi^{2}$ \\
\hline Initial status $\left(r_{0}\right)$ & $7.481^{* * *}$ & 2.735 & $2,154.340$ \\
Rate of change $\left(r_{1}\right)$ & $.140^{* * *}$ & .373 & $1,272.997$ \\
Residual $(e)$ & 13.726 & 3.705 & \\
${ }^{* * *} p<.001$. & & & \\
& & &
\end{tabular}

Table 4. The effects of variables on changes in cognitive function

\begin{tabular}{|c|c|c|c|}
\hline Fixed effect & Coefficient & SE & $t$ \\
\hline \multicolumn{4}{|l|}{ Initial status } \\
\hline Intercept $\left(\beta_{00}\right)$ & $27.097^{* * *}$ & .585 & 46.333 \\
\hline Age $\left(\beta_{01}\right)$ & $-.110^{* * *}$ & .024 & -4.638 \\
\hline Education level $\left(\beta_{02}\right)$ & $1.040^{* * *}$ & .094 & 11.038 \\
\hline Economic condition $\left(\beta_{03}\right)$ & $.016^{* *}$ & .005 & 3.139 \\
\hline \multicolumn{4}{|l|}{ Rate of change } \\
\hline Intercept $\left(\beta_{10}\right)$ & $-.674^{* * *}$ & .193 & -3.496 \\
\hline Age $\left(\beta_{11}\right)$ & -.010 & .005 & -1.912 \\
\hline Education level $\left(\beta_{12}\right)$ & $-.060^{*}$ & .023 & -2.572 \\
\hline Economic condition $\left(\beta_{13}\right)$ & -.001 & .001 & -.814 \\
\hline Subjective health condition $\left(\beta_{20}\right)$ & .048 & .103 & .470 \\
\hline Depression level $\left(\beta_{30}\right)$ & $-.178^{* * *}$ & .032 & -5.632 \\
\hline Subjective hearing condition $\left(\beta_{40}\right)$ & $.394^{* *}$ & .129 & 3.071 \\
\hline Social contract $\left(\beta_{50}\right)$ & -.023 & .028 & -832 \\
\hline Subjective health condition* Time $\left(\beta_{60}\right)$ & $.309 * * *$ & .034 & 8.968 \\
\hline Depression level ${ }^{*}$ Time $\left(\beta_{70}\right)$ & $-.039 * * *$ & .010 & -3.954 \\
\hline Subjective hearing condition ${ }^{*}$ Time $\left(\beta_{80}\right)$ & $-109^{* *}$ & .038 & -3.954 \\
\hline Social contract* Time $\left(\beta_{90}\right)$ & .004 & .009 & .450 \\
\hline Random effect & Variance & SD & $x^{2}$ \\
\hline Initial status $\left(r_{0}\right)$ & $4.665^{* * *}$ & 2.160 & $1,786.421$ \\
\hline Rate of change $\left(r_{1}\right)$ & $.132^{* * *}$ & .363 & $1,277.224$ \\
\hline Residual (e) & 12.366 & 3.517 & \\
\hline
\end{tabular}

${ }^{*} p<.05,{ }^{* *} p<.01,{ }^{* * *} p<.001$. 
화율에 대한 고정효과를 분석한 결과, 1 차 조사 시점에서 노년층의 인지기능 평균 $\left(\beta_{00}\right)$ 은 26.026 , 측정 시점에 따른 인지기능 변화율의 평균 $\left(\beta_{10}\right)$ 은 -.317로 선형적으로 감소하였다. 무선효과 분석 결과, 초기치 $\left(\mathrm{r}_{0}\right)$ 와 변화율 $\left(\mathrm{r}_{1}\right)$ 의 분산이 모두 유의하게 나타나서, 노년층 의 인지기능의 초기치와 측정 시점에 따른 변화율에 있어서 개인 간 차이가 있는 것으로 나타났다 $(p<.001)$.

\section{인지기능의 종단적 변화에 대한 영향 요인}

노년층과 관련된 요인들이 인지기능에 어떠한 영향을 미치는지 알아보기 위하여, 1 수준의 측정 시점과 주관적 건강상태, 우울수 준, 주관적 청력상태, 사회적 접촉, 각 시간의존적 변수와 측정 시점 의 상화작용항, 2 수준에는 연령, 교육수준, 경제상태 요인을 투입하 여 연구모형을 분석하였다. 연구모형 분석 결과는 Table 4 와 같다.

노년층의 인지기능 초기치의 평균 $\left(\beta_{00}\right)$ 은 27.097이며, 연령, 교육 수준, 경제상태 요인이 인지기능의 초기치에 미치는 영향이 유의한 것으로 나타났다 $(p<.001) .1$ 차 조사 시점에서의 연령이 높을수록 ( $\beta=-.110, p<.001)$, 교육수준이 낮을수록 $(\beta=1.040, p<.001)$, 경제
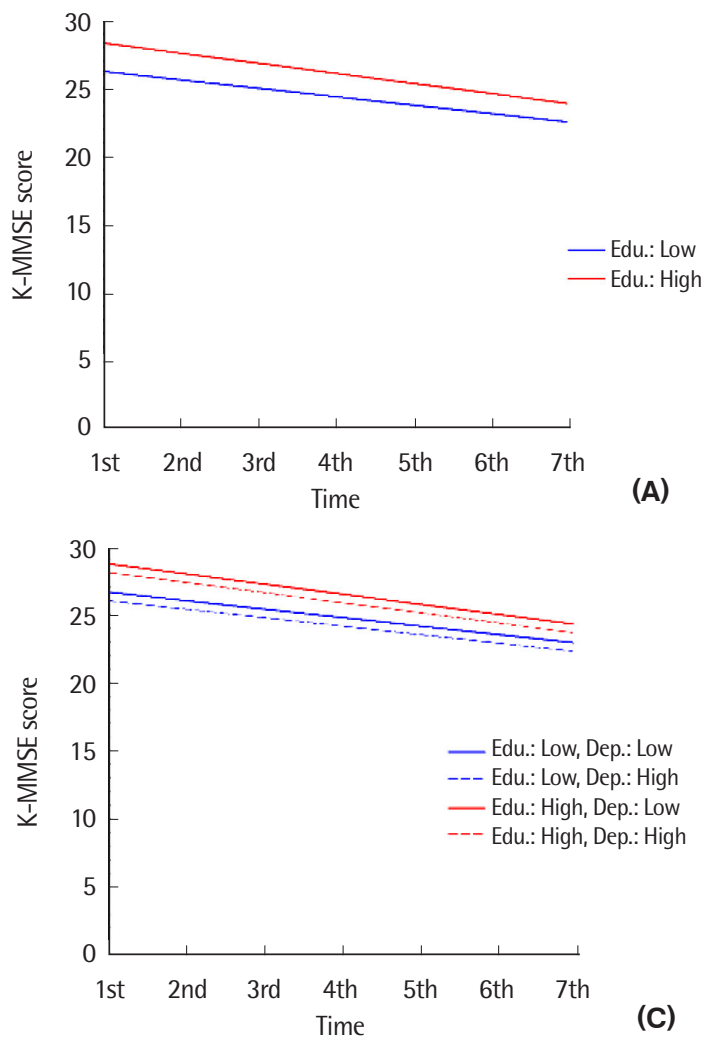

상태가 낮을수록 $(\beta=.016, p<.01)$ 인지기능이 유의하게 낮게 나타 났다. 노년층의 인지기능 변화율의 평균( $\left.\beta_{10}\right)$ 은 -.674이며 통계적으 로 유의하게 나타났다 $(p<.001)$. 이는 노년층의 인지기능이 시간의 흐름에 따라 선형적으로 감소하여 1차 조사 시점부터 7 차 조사 시 점까지 매 측정 시점마다 인지기능이 저하됨을 의미한다. 이러한 인지기능의 변화에 영향을 미치는 요인을 살펴보면, 교육수준에 따라 인지기능의 변화율이 유의하게 증가하는 것으로 나타났다 $(\beta=-.060, p<.05)$. 이에 따라, 대상자의 교육수준을 상위와 하위 집단으로 구분하여 인지기능의 변화를 살펴본 결과, 교육수준이 높은 집단의 인지기능 초기치가 교육수준이 낮은 집단에 비해서 높았으며, 교육수준의 높은 집단의 인지기능의 변화율이 교육수 준이 낮은 집단에 비해서 크게 나타났다(Figure $1 \mathrm{~A}$ ). 반면, 연령 $(\beta=-.010, p>.05)$ 및 경제상태 $(\beta=-.001, p>.05)$ 는 시간의 흐름에 따른 인지기능의 변화율에 유의한 영향을 미치지 않았다.

1 수준에 투입한 시간의존적 변수가 인지기능에 어떠한 영향을 미치는지 살펴본 결과, 우울수준 $(\beta=-.178, p<.001)$ 및 주관적 청 력상태 $(\beta=.394, p<.01)$ 가 인지기능에 미치는 영향이 유의한 것으
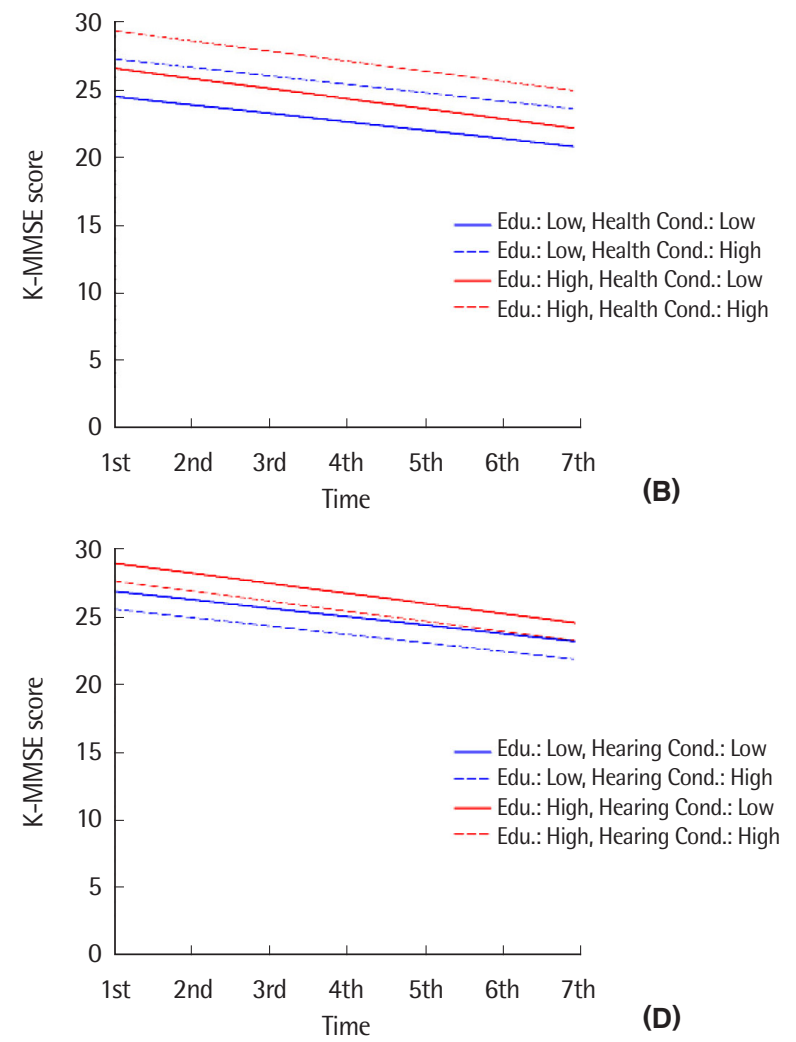

Figure 1. Longitudinal change in cognitive function: (A) the difference between lower and higher groups on education level, (B) the difference between groups on education levels and subjective health conditions, (C) the difference between groups on education levels and depression levels, (D) the difference between groups on education levels and subjective hearing conditions.

Edu. = Education Level; Health Cond. = Subjective Health Condition; Dep. = Depression Level; Hearing Cond. = Subjective Hearing Condition . 
로 나타났다. 즉, 노년층의 우울수준이 높을수록, 주관적 청력상태 가 나쁠수록 인지기능이 낮게 나타났다. 반면, 주관적 건강상태 ( $\beta=.048, p>$.05)와사회적 접촉 $(\beta=-.023, p>.05)$ 은 인지기능에 미 치는 영향이 유의하지 않았다.

1 수준에서 시간의존적 변수와 측정 시점의 상호작용항을 투입 하여 각 시간의존적 변수의 영향력이 시간의 흐름에 따라 변화하 는지 시간의존적 효과를 살펴본 결과, 주관적 건강상태와 측정 시 점의 상호작용 $(\beta=.309, p<.001)$, 우울수준과 측정 시점의 상호작 용 $(\beta=-.039, p<.001)$, 주관적 청력상태와 측정 시점의 상호작용 $(\beta=-.109, p<.01)$ 이 통계적으로 유의하였다. 이는 주관적 건강상 태가 인지기능에 미치는 영향력이 시간의 흐름에 따라 증가하는 반면, 우울수준과 주관적 청력상태는 인지기능에 미치는 영향력이 시간의 흐름에 따라 감소하는 것을 의미한다. 이에 따라 인지기능 에 유의한 영향을 미치는 변수인 교육수준과 주관적 건강상태, 우 울수준, 주관적 청력상태 각각을 상위와 하위 집단으로 나누어 집 단 별로 인지기능 변화 궤적을 살펴보았으며, 교육수준이 동일한 집단 내에서도 주관적 건강상태, 우울수준, 주관적 청력상태 각각 에 따라 인지기능의 종단적 변화에 차이를 보이는 것을 확인하였 다. 주관적 건강상태가 인지기능의 변화에 미치는 정적 영향은 유 의하지 않았으나, 시간의 흐름에 따라 인지기능 변화에 미치는 영 향력이 증가하는 모습을 보였다(Figure 1B). 다음으로, 우울수준이 높은 경우 우울수준이 낮은 경우에 비해 인지기능의 저하가 큰 것 으로 나타났다(Figure 1C). 그러나 이러한 우울수준이 인지기능에 미치는 부적 영향은 시간의 흐름에 따라 감소하였다. 마지막으로, 주관적 청력상태가 낮은 경우 주관적 청력상태가 높은 경우에 비 해 인지기능의 저하가 큰 것으로 나타났으나, 이러한 주관적 청력상 태가 인지기능에 미치는 정적 영향은 시간의 흐름에 따라 감소하 는 것으로 나타났다(Figure 1D). 반면, 사회적 접촉과 측정 시점의 상호작용은 유의하지 않아 인지기능에 미치는 영향력이 시간의 흐 름에 따라 유의한차이가 없는 것으로 나타났다( $\beta=.004, p>.05)$.

\section{논의 및 결론}

본 연구에서는 1 차부터 7 차까지의 고령화연구패널조사 자료를 활용하여 노년층의 인지기능이 시간의 흐름에 따라 어떻게 변화하 는지, 사회인구학적 요인, 신체적 - 정신적인 건강상태 요인, 청력 요 인, 사회적인 접촉 요인이 노년층의 인지기능 변화에 어떠한 영향 을 미치는지 다층성장모형 분석을 통해 검증하였다. 본 연구의 결 과에 따른 논의는 다음과 같다.

본 연구에서 노년층의 인지기능이 시간의 흐름에 따라 선형적으
로 감소하는 것을 확인하였다. 이는 노년층을 대상으로 인지기능의 변화를 종단적으로 살펴본 선행연구에서 노년층의 인지기능이 시 간이 경과함에 따라 감소한다는 결과와 일치한다(Baik, 2015; Wilson et al., 2002; Yang, Jeong, \& Choi, 2017). 여기서 주목할 점은 노 년층의 인지기능의 초기치와 변화율에는 개인 간 차이가 존재한다 는 것이다. 즉, 대체적으로 노년층의 인지기능이 시간의 흐름에 따 라서 감소하는 추세로 나타나지만, 인지기능의 초기치와 변화의 정 도는 개인적 특성을 비롯한 여러 영향 요인에 따라 차이가 존재함 을 의미한다.

사회인구학적 요인 중 연령, 교육수준, 경제상태가 1 차 조사 시점 의 노년층의 인지기능에 영향을 미치는 것으로 나타났으며, 이 중 교육수준만 시간의 흐름에 따른 노년층의 인지기능의 변화율에 영 향을 미치는 것으로 나타났다. 먼저, 인지기능의 초기치에 영향을 미치는 요인을 살펴보면 1차 조사 시점에서 연령이 높을수록, 교육 수준이 낮을수록, 경제상태가 나쁠수록 인지기능이 낮은 것으로 나타났다. 이는 연령 집단 간의 인지기능 차이를 살펴본 기존 선행 연구 결과와 일치한다(Choi \& Sung, 2019; Hultsch, Hertzog, \& Dixon, 1990; Klencklen et al., 2017; Lee et al., 2012; Sung \& Kwag, 2012). 그리고 노년층의 인지기능에 대한 교육수준의 영향력을 살 펴본 선행연구 결과와 일치하였으며(Kim, 2010; Mirowsky \& Ross, 2005; Won \& Kim, 2003), Won과 Kim (2003)은 교육수준이 노인 의 인지기능에 가장 큰 영향을 미친다고 하였다.

또한 노년층의 인지기능에 대한 경제상태의 부적인 영향력을 확 인한 선행연구 결과(Jeon, 2013; Kim et al, 2011)와 일치하였다. 이 러한 연구결과는 노년층의 경제적 상태가 단순히 일상생활에서 겪 게 되는 생활영위의 어려움에만 영향을 미치는 것뿐만 아니라 인 지기능과 같은 건강 불평등에도 영향을 미칠 수 있다는 것을 시사 한다. 그러므로 경제적 빈곤 계층에 속해 있는 노년층을 대상으로 하는 다영역적인 평가와 문제 개선을 위한 의료 및 사회복지 시스 템 마련이 필요할 것이다.

다음으로, 인지기능의 변화율에 영향을 미치는 요인을 살펴보면 교육수준이 높을수록 시간의 흐름에 따라 인지기능의 감소폭이 커지는 것으로 나타났다. 노년층을 대상으로 시간의 흐름에 따른 인지기능의 변화에 교육수준이 미치는 영향을 살펴본 선행연구의 결과를 살펴보면 교육수준이 노화에 따른 인지기능 저하를 완화 하지 못한다고 보고하고 있다(Christensen et al., 2001; Tucker-Drob, Johnson, \& Jones, 2009; Van Dijk et al., 2008; Zahodne et al., 2011). 기존 선행연구에서 교육수준이 인지기능 변화율에 미치는 영향이 유의하지 않다고 보고하고 있는 것과 달리 본 연구에서 교육수준 이 높을수록 인지기능의 감소폭이 증가하는 이유는 다음과 같이 
예상된다. 첫째, 노년층의 인지기능을 측정하는 측정도구의 차이가 결과에 영향을 미쳤을 것으로 판단된다. 기존 선행연구에서는 작 업기억, 구어 유창성, 처리속도 등 인지기능의 하위영역을 세부적 으로 나누어 각 하위영역 별로 인지기능을 측정하였으나 본 연구 에서는 K-MMSE를 측정도구로 사용하여 인지기능의 하위영역을 구분하지 않고 전반적인 인지기능을 측정한 점에서 차이가 있었다. 둘째, 인지기능의 변화율에 교육수준이 높은 집단과 낮은 집단으 로 나누어 살펴보았을 때 교육수준이 높은 집단의 인지기능의 초 기치가 인지기능 측정도구인 K-MMSE의 최고 점수(30점)에 가깝 게 높은 것이 영향을 미쳤을 것으로 판단된다. 교육수준이 높은 집 단은 교육수준이 낮은 집단에 비해 인지기능의 감소폭이 컸음에도 모든 조사 시점에서 인지기능이 높게 나타났다.

본 연구에서는 노년층의 신체적·정신적인 건강상태 요인이 인지 기능에 영향을 미치는 것으로 나타났다. 우울수준이 높을수록 인 지기능이 낮은 것으로 나타났으며, 이러한 우울수준의 영향력은 시간의 흐름에 따라 감소하는 것으로 나타났다. 이는 우울증상을 인지기능 저하의 영향 요인으로 보고하고 있는 기존 선행연구 결과 와 일치한다(Chodosh et al., 2007; Paterniti, Verdier-Taillefer, Dufouil, \& Alpérovitch, 2002). Paterniti 등(2002)은 Center for Epidemiological Studies-Depression Scale (CES-D; Radloff, 1977)로 우 울증상을 측정하고, Mini-Mental State Examination (MMSE; Folstein, Folstein, \& McHugh, 1975)으로 인지기능을 측정하여 본 연 구와 동일한 측정도구를 사용하여 초기 시점과 2년 후, 4 년 후 시점 의 우울증상 및 인지기능을 측정한 결과, 우울증상의 지속이 노년 층의 인지기능 감퇴와 관련 있음을 보고하였다. Chodosh 등(2007) 은 Hopkins Symptom Check List (HSCL; Derogatis, Lipman, Rickels, Uhlenhuth, \& Covi, 1974)로 우울증상을 측정하고, Short Portable Mental Status Questionnaire (SPMSQ; Pfeiffer, 1975)로 인지 기능을 측정하여 초기 시점과 7년간의 시점의 우울증상 및 인지기 능을 측정한 결과, 우울증상이 인지기능 감퇴를 예측하는 요인임 을 보고하였다. 반면 주관적 건강상태는 노년층의 인지기능에 영향 을 미치지 않았으나 인지기능의 변화에 미치는 영향이 시간의 흐름 에 따라 증가하는 것으로 나타났다. 이는 노년층의 인지기능에 대 한 주관적 건강상태의 정적인 영향을 보고한 선행연구의 결과와 차이가 있다(Lee, 2014; Seo \& So, 2016; Steverink et al., 2001). 그러 나 Fabbri 등(2016)은 만성질환을 않고 있는 경우 인지기능 감퇴를 가속시킨다고 보고하였으며, 이는 주관적 건강상태의 영향력이 시 간의 흐름에 따라 유의하게 커짐을 보고한 본 연구의 결과와 일부 맥락을 같이 한다.

본 연구에서 노년층의 청력 요인이 노년층의 인지기능에 영향을
미치는 것으로 나타났다. 노년층이 지각한 주관적 청력상태가 나 쁠수록 인지기능이 낮은 것으로 나타났으며, 이러한 주관적 청력 상태의 영향력은 시간의 흐름에 따라 감소하는 것으로 나타났다. 이는 주관적인 보고를 통해 주관적 청력상태를 측정한 선행연구에 서 주관적 청력저하가 인지기능 감퇴에 영향을 미친다고 보고한 결 과와 일치한다(Amieva et al., 2015; Gurgel et al., 2014; Han, 2018). 또한 순음청력검사(pure-tone audiometry)를 실시하여 객관적인 청력상태를 측정한 선행연구에서도 난청이 인지기능 감퇴에 영향 을 미친다고 보고하고 있다(Kiely, Gopinath, Mitchell, Luszcz, \& Anstey, 2012; Lin et al., 2013). 본 연구에서 노년층의 주관적인 청력 상태는 단순히 청력역치(hearing threshold)와 정비례적인 관계가 아니기 때문에 주의를 기울여서 해석할 필요는 있다. 예를 들면, 난 청 노인 중에서 본인의 청력에 적절한 보청기를 착용하고 가족 및 지인들과 의사소통을 원활하게 잘 하고 있는 상태라면, 당사자가 지각하는 주관적 청력상태는 양호할 수 있다. 난청 노인 중에서 본 인의 청각장애 문제를 방치한 채 보청기 착용을 하고 있지 않다면, 주관적인 청력상태는 나쁠 수 있다. 노년층의 청력상태는 청각장애 의 심각도 외에 청력검사, 보청기 착용, 청능재활 등과 같은 적절한 의료 및 복지 시스템의 접근성에 따라 영향을 받을 수 있다(Lee \& Park, 2021). 즉, 노년층이 경험하는 주관적인 청력상태는 당사자의 청력역치 뿐만 아니라 여러 요인들에 의해 결정될 수 있는 것이다 (Lee, Park, \& Lee, 2020). 이러한 관점에서 볼 때, 청력 요인으로 인 한 인지 저하는 노년층을 대상으로 한 청각장애의 선별검사, 적절 한 재활 실시 등과 같은 의료, 보건, 사회복지 간의 유기적인 시스템 마련으로 최소화될 수 있을 것이다.

마지막으로, 사회적 접촉 요인은 노년층의 인지기능에 영향을 미 치지 않는 것으로 나타났다. 이는 사회적 접촉이 인지기능과 관련 이 없다고 보고한 Seeman 등(2001)의 연구결과와 일치한다. 또한 사회적 접촉이 인지기능에 미치는 영향을 살펴본 일부 선행연구 결 과와 부분적으로 일치한다(Fratiglioni et al., 2000; Jeon, 2013). Fratiglioni 등(2000)은 가까운 친구나 친지가 없는 등 사회적 연결망이 부재하는 경우 치매 발병 위험이 증가한다고 보고하고 있으나사회 적 접촉 빈도는 치매 발병을 예측하지 못한다고 보고하였다. 일부 선행연구에서는 노년층의 사회적 접촉 요인을 사회활동의 수와 사 회적 접촉 빈도로 나누어 살펴보았으며, 사회활동의 수는 종교모 임, 자원봉사, 여가활동, 친목모임 등 참여하는 사회활동의 수를 묻 는 문항, 사회적 접촉 빈도는 친구, 친척, 이웃 등 친한 사람들과 얼 마나 자주 만나는지를 묻는 문항으로 측정하였다(Jeon, 2013; Lee, 2016). Jeon (2013)은 사회활동의 수는 인지기능에 영향을 미치나 사회적 접촉 빈도는 인지기능에 영향을 미치지 않는다고 보고하였 
다. 반면, Lee (2016)는 사회활동의 수는 인지기능에 영향을 미치지 않지만 사회적 접촉 빈도는 인지기능에 영향을 미친다고 보고하였 다. 이와 같이 사회적 접촉이 노년층의 인지기능에 미치는 영향에 대한 선행연구의 결과는 일관되게 나타나지 않았다. 이처럼 노년층 의 사회적 접촉이 인지기능에 미치는 영향력에 대한 결과가 비일관 적으로 나타나는 것은 사회적 접촉이 가지는 속성과 관련이 있을 것으로 생각된다. 사회적 접촉은 접촉 빈도나 참여하는 사회활동 의 수와 같은 구조적 측면 외에 사회활동 참여에 수반되는 사회지 지나 사회갈등과 같은 질적 측면을 포함하고 있다(Kim, 2015). 그 러나 이에 대한 개념정의나 측정방법은 연구마다 다양하며, 사회적 접촉의 속성 중 일부 요소만 측정하고 있어 사회적 접촉이 인지기 능에 미치는 영향력을 살펴보았을 때 그 결과가 상이하게 나타나 는 것으로 보인다.

이상의 연구결과를 바탕으로 한 본 연구의 의의는 다음과 같다. 먼저, 본 연구는 전국 단위의 대규모 패널자료인 고령화연구패널조 사 자료를 활용하여 노년층의 인지기능이 선형적으로 감소하는 것 을 확인하였으며, 교육수준, 우울수준, 주관적 청력상태가 노년층 의 인지기능 감소에 영향을 미치는 요인임을 확인하였다는 점에서 의의가 있다. 즉, 교육수준이 낮을수록, 우울수준이 높을수록, 주 관적 청력상태가 나쁠수록 정상적인 노화 과정에서 나타나는 인지 기능 감퇴를 벗어나 경도인지장애 및 치매로 진행될 위험이 큰 위 험군으로 분류할 수 있으며, 인지기능 감퇴를 예방하기 위해 우울 증상 및 청력저하에 대한 관리가 함께 이루어지는 것이 효과적임 을 의미한다. 이러한 점을 고려하였을 때 고령화로 인해 야기되는 사회적 문제에 대처하기 위한 노인복지정책의 필요성이 대두되고 있는 현 상황에서 치매 예방과 관련된 정책 마련 시 기초자료로 활 용될 수 있을 것으로 예상된다. 다음으로, 본 연구에서는 조사 시점 에 따라 신체적.정신적인 건강상태, 청력, 사회적인 접촉 정도가 변 화할 수 있다는 점을 고려하여 이와 같은 변수를 시간의존적 변수 로 투입하였으며, 시간과의 상호작용을 통하여 각 변수가 노년층의 인지기능에 미치는 영향력이 시간의 흐름에 따라 어떻게 달라지는 지 양상을 확인하였다는 점에서 의의가 있다. 노년층의 인지기능 감소의 영향 요인으로 나타난 우울수준과 주관적 청력상태의 영향 력은 시간의 흐름에 따라 감소하는 것으로 나타났는데, 이는 우울 수준이 높은 노인과 주관적 청력상태가 나쁜 노인의 경우 각각 우 울수준이 낮은 노인과 주관적 청력상태가 좋은 노인과 비교하여 이미 인지기능이 크게 저하되어 있기 때문에 이후 저하 폭이 차츰 감소하는 것으로 볼 수 있다. 따라서 우울증상과 청력저하의 발생 초기에 인지기능에 미치는 영향이 크므로 이를 조기에 선별하고 적절한 중재가 이루어지는 것이 인지기능 감퇴를 예방하는데 중요
하며, 우울증상과 청력저하의 조기 선별 및 중재를 위한 제도적 방 안이 고안될 필요가 있음을 시사한다.

끝으로 본 연구의 한계점과 후속연구에 대한 제언은 다음과 같 다. 첫째, 청력상태를 노년층의 자기보고에 근거하여 측정한 한계가 있다. 자기보고를 통한 주관적 청력평가가 충분히 정확하다는 연구 결과도 있으나(Ferrite, Santana, \& Marshall, 2011), 연령이 높을수 록, 교육수준이 낮을수록 자신의 청력을 과소평가하는 경향도 있 다고 보고한 연구 결과도 있다(Kamil, Genther, \& Lin, 2015). 따라 서 객관적인 청력검사를 통해 청력이 인지기능에 미치는 종단적 영 향력을 검증하는 연구가 이루어질 필요가 있다. 둘째, 패널자료의 특성상 제한된 문항을 통해 각 요인들이 측정되었기 때문에 결과의 질 측면에서 매우 선별적인 한계가 있다. 따라서 추후 연구에서는 본 연구에서 사용된 문항 외에 다양한 유형의 측정도구를 활용하 여 각 요인의 질적인 측면을 충분히 반영할 필요가 있을 것이다. 예 를 들면, 본 연구에서는 노년층 인지기능 저하의 영향 요인으로 나 타난 우울수준 및 주관적 청력상태와 관련하여 우울증상 및 청력 저하가 지속된 기간, 중재 여부 및 기간 등 질적인 차이를 고려하지 못하였지만 추후 연구에서는 이와 같은 노년층의 인지기능에 영향 을 미치는 요인의 질적인 차이를 반영하여 그 영향력을 살펴본다면 심도 있는 연구가 진행될 수 있을 것이다. 마지막으로, 본 연구에서 는 노년층의 인지기능 저하에 여러 요인들이 복합적으로 작용할 수 있음을 고려하여 사회인구학적인 요인, 신체적.정신적 건강 요인, 청 각 요인, 사회적 접촉 요인의 다섯 가지 요인을 선정하여 노년층의 인지기능 저하에 미치는 영향력을 포괄적으로 살펴보고자 하였다. 그러나 일부 선행연구에서 노년층의 인지기능 저하의 영향 요인으 로 보고되고 있는 시각 및 운동 등의 요인을 포함하지 못한 한계가 있다. 시각 요인에 대한 선행연구에서는 시력 저하를 경험하는 노인 의 경우 인지기능 손상의 위험이 더 높은 것으로 보고하고 있으며 (Clemons, Rankin, \& McBee, 2006; Kim et al., 2011), 운동 요인에 대한 선행연구에서는 꾸준한 운동과 같은 신체활동에 참여하는 것 이 노년층의 인지기능을 유지하고 개선하는데 긍정적인 영향을 미 친다고 보고하고 있다(Grotz et al., 2017; Iuliano et al., 2019; Jeon 2013; Kim, Park, \& Park, 2020). 따라서 시각 및 운동 등의 요인을 비롯하여 노년층의 인지기능 저하에 영향을 미칠 수 있는 요인을 더 욱 폭넓게 살펴본 연구가 이루어질 필요가 있을 것이다.

\section{REFERENCES}

Amieva, H., Ouvrard, C., Giulioli, C., Meillon, C., Rullier, L., \& Dartigues, J. F. (2015). Self-reported hearing loss, hearing aids, and cognitive decline in 
elderly adults: a 25-year study. Journal of the American Geriatrics Society, 63(10), 2099-2104.

Bahar-Fuchs, A., Clare, L., \& Woods, B. (2013). Cognitive training and cognitive rehabilitation for persons with mild to moderate dementia of the Alzheimer's or vascular type: a review. Alzheimer's Research \& Therapy, 5(4), 1-14.

Baik, O. M. (2015). The trajectory and its predictors of the change of cognitive functioning among the elderly-a latent growth curve analysis. Locality and Globality, 39(3), 79-103.

Barnes, D. E., Blackwell, T., Stone, K. L., Goldman, S. E., Hillier, T., Yaffe, K., \& Study of Osteoporotic Fractures. (2008). Cognition in older women: the importance of daytime movement. Journal of the American Geriatrics Society, 56(9), 1658-1664.

Brookmeyer, R., Gray, S., \& Kawas, C. (1998). Projections of Alzheimer's disease in the United States and the public health impact of delaying disease onset. American Journal of Public Health, 88(9), 1337-1342.

Burstein, L. (1980). The analysis of multilevel data in educational research and evaluation. Review of Research in Education, 8(1), 158-233.

Chodosh, J., Kado D., Seeman, T., Karlamangla, A. (2007). Depressive symptoms as a predictor of cognitive decline. The American Journal of Geriatric Psychiatry, 15(5), 406-415.

Chodosh, J., Miller-Martinez, D., Aneshensel, C. S., Wight, R. G., \& Karlamangla, A. S. (2010). Depressive symptoms, chronic diseases, and physical disabilities as predictors of cognitive functioning trajectories in older Americans. Journal of the American Geriatrics Society, 58(12), 2350-2357.

Choi, S., \& Sung, J. E. (2019). Age-related decline in storage and processing components of working memory: an eye-tracking study. Communication Sciences \& Disorders, 24(1), 205-219.

Choi, S., Sung, J. E., \& Jeong, J. H. (2020). Differential deficits of nouns and verbs in a generative naming task for individuals with mild cognitive impairment. Communication Sciences \& Disorders, 25(1), 50-62.

Clemons, T. E., Rankin, M. W., \& McBee, W. L. (2006). Cognitive impairment in the age-related eye disease study: AREDS report no. 16. Archives of Ophthalmology (Chicago, Ill.: 1960), 124(4), 537-543.

Cooley, W., Bond, L., \& Mao, B. (1981). Analyzing multilevel data. In R. Berk (Ed.), Educational evaluation methodology (pp. 64-83). Baltimore, MD: Johns Hopkins University Press.

Christensen, H., Hofer, S. M., MacKinnon, A. J., Korten, A. E., Jorm, A. F., \& Henderson, A. S. (2001). Age is no kinder to the better educated: absence of an association investigated using latent growth techniques in a commu- nity sample. Psychological Medicine, 31(1), 15-28.

Cronbach, L. J., \& Webb, N. (1975). Between-class and within-class effects in a reported aptitude $\mathrm{X}$ treatment interaction: reanalysis of a study by G. L. Anderson. Journal of Educational Psychology, 67(6), 717-724.

Derogatis, L. R., Lipman, R. S., Rickels, K., Uhlenhuth, E. H., \& Covi, L. (1974). The Hopkins Symptom Checklist (HSCL): a self-report symptom inventory. Behavioral Science, 19(1), 1-15.

Fabbri, E., An, Y., Zoli, M., Tanaka, T., Simonsick, E. M., Kitner-Triolo, M. H., ..., \& Ferrucci, L. (2016). Association between accelerated multimorbidity and age-related cognitive decline in older Baltimore Longitudinal Study of Aging participants without dementia. Journal of the American Geriatrics Society, 64(5), 965-972.

Ferrite, S., Santana, V. S., \& Marshall, S. W. (2011). Validity of self-reported hearing loss in adults: performance of three single questions. Revista de Saude Publica, 45(5), 824-830.

Folstein, M. F., Folstein, S. E., \& McHugh, P. R. (1975). "Mini-mental state”: a practical method for grading the cognitive state of patients for the clinician. Journal of Psychiatric Research, 12(3), 189-198.

Fratiglioni, L., Wang, H., Ericsson, K., Maytan, M., \& Winblad, B. (2000). Influence of social network on occurrence of dementia. The Lancet, 355(9212), 1315-1319.

Grotz, C., Matharan, F., Amieva, H., Pérès, K., Laberon, S., Vonthron, A. M., ..., \& Letenneur, L. (2017). Psychological transition and adjustment processes related to retirement: influence on cognitive functioning. Aging \& Mental Health, 21(12), 1310-1316.

Gurgel, R. K., Ward, P. D., Schwartz, S., Norton, M. C., Foster, N. L., \& Tschanz, J. T. (2014). Relationship of hearing loss and dementia: a prospective, population-based study. Otology \& neurotology: official publication of the American Otological Society, American Neurotology Society and European Academy of Otology and Neurotology, 35(5), 775-781.

Han, J. H. (2018). Association between self-reported hearing impairment and cognitive function Korean Longitudinal Study of Aging (2006-2014) data analysis (Doctoral dissertation), Yonsei University, Seoul, Korea.

Hayden, K. M., Reed, B. R., Manly, J. J., Tommet, D., Pietrzak, R. H., Chelune, G. J., ..., \& Jones, R. N. (2011). Cognitive decline in the elderly: an analysis of population heterogeneity. Age and Ageing, 40(6), 684-689.

Hultsch, D. F., Hertzog, C., \& Dixon, R. A. (1990). Ability correlates of memory performance in adulthood and aging. Psychology and Aging, 5(3), 356368.

Hwang, J. N., \& Kwon, S. M. (2009). The relation between the participation 
in social activity and cognitive function among middle-aged and elderly population. Journal of the Korean Gerontological Society, 29(3), 971-986.

Iuliano, E., di Cagno, A., Cristofano, A., Angiolillo, A., D’Aversa, R., Ciccotelli, S., ..., \& Di Costanzo, A. (2019). Physical exercise for prevention of dementia (EPD) study: background, design and methods. BMC Public Health, 19(1), 1-9.

James, B. D., Wilson, R. S., Barnes, L. L., \& Bennett, D. A. (2011). Late-life social activity and cognitive decline in old age. Journal of the International Neuropsychological Society, 17(6), 998-1005.

Jeon, H. S. (2013). An exploratory study on the predictors of cognitive improvement among older adults: using Korean Longitudinal Study of Aging (KLoSA). Health and Social Welfare Review, 33(2), 461-488.

Jeon, K. K., Choi, S. J., \& Yang, B. C. (2001). Integrated Adaptation of CES-D in Korea. The Korean Journal of Health Psychology, 6(1), 59-76.

Kamil, R. J., Genther, D. J., \& Lin, F. R. (2015). Factors associated with the accuracy of subjective assessments of hearing impairment. Ear and Hearing, 36(1), 164-167.

Kang, S. (2016). Multilevel models. Seoul: Hakjisa.

Kang, Y. (2006). A normative study of the Korean-Mini Mental State Examination (K-MMSE) in the elderly. Korean Journal of Psychology: General, 25(2), 1-12.

Kiely, K. M., Gopinath, B., Mitchell, P., Luszcz, M., \& Anstey, K. J. (2012). Cognitive, health, and sociodemographic predictors of longitudinal decline in hearing acuity among older adults. Journals of Gerontology Series A: Biomedical Sciences and Medical Sciences, 67(9), 997-1003.

Kim, E. J. (2010). Factors influencing cognitive impairment of the elderly residents. Journal of East-West Nursing Research, 16(2), 122-130.

Kim, H. J., Kim, B. H., \& Kim, O. S. (2011). The effect of visual and hearing impairment on depression and cognitive function in community-dwelling elderly: the Korean Longitudinal Study of Aging 2008. Korean Journal of Adult Nursing, 23(6), 584-594.

Kim, H. Y. (2015). Social life and cognitive function in old age. Korean Journal of Psychology: General, 34(1), 225-251.

Kim, J., Park, K., \& Park, H. (2020). Analysis of cognitive function changes and influence factors in the elderly: an application of latent growth modeling. Korean Journal of Sociology of Sport, 33(3), 1-20.

Klencklen, G., Lavenex, P. B., Brandner, C., \& Lavenex, P. (2017). Working memory decline in normal aging: Memory load and representational demands affect performance. Learning and Motivation, 60, 10-22.

Kwon, Y. S., \& Paek, K. S. (2014). Factors associated with cognitive decline in the elderly in community. Journal of Digital Convergence, 12(2), 587-594.

Lee, H. J., \& Kahng, S. K. (2011). Age and gender differences in cognitive functioning among elderly. Mental Health and Social Work, 37, 255-278.

Lee, H. W., Kim, S. K., Lee, K. E., Chung, E. J., \& Park, J. Y. (2012). The agerelated changes in cognitive function. Korean Journal of Cognitive and Biological Psychology, 24(2), 127-148.

Lee, S. E. (2014). The relationship between hand grip strength and cognitive function in older adults: the moderating effect of regular exercise. The Korean Journal of Community Living Science, 25(1), 29-37.

Lee, S. E. (2016). Factors affecting cognitive function in older persons with hearing impairment. Korean Speech- Language \& Hearing Association, 25(4), 263-272.

Lee, S. J. (2018). The relationship between hearing impairment and cognitive function in middle-aged and older adults: a meta-analysis. Communication Sciences \& Disorders, 23(2), 378-391.

Lee, Y., \& Park, S. (2021). A comprehensive guide to hearing loss for older adults. Seoul: Hakjisa.

Lee, Y., Park, S., \& Lee, S. J. (2020). Exploring factors related to self-perceived hearing handicap in the elderly with moderate to moderately-severe hearing loss. Communication Sciences \& Disorders, 25(1), 142-155.

Lee, Y., Na, D. L., Cheong, H. K., Hong, C. H., Back, J. H., Kim, J., ..., \& Kim, Y. G. (2009). Lifestyle recommendations for dementia prevention: PASCAL. Journal of the Korean Geriatrics Society, 13(2), 61-68.

Light, L. L. (1991). Memory and aging: four hypotheses in search of data. Annual Review of Psychology, 42(1), 333-376.

Lin, F. R., Ferrucci, L., Metter, E. J., An, Y., Zonderman, A. B., \& Resnick, S. M. (2011). Hearing loss and cognition in the Baltimore Longitudinal Study of Aging. Neuropsychology, 25(6), 763-770.

Lin, F. R., Yaffe, K., Xia, J., Xue, Q. L., Harris, T. B., Purchase-Helzner, E., ..., \& Health ABC Study Group, F. (2013). Hearing loss and cognitive decline in older adults. JAMA Internal Medicine, 173(4), 293-299.

Mirowsky, J., \& Ross, C. E. (2005). Education, cumulative advantage, and health. Ageing International, 30(1), 27-62.

National Institute of Dementia. (2019). Korean Dementia observatory 2019. Retrieved from https://www.nid.or.kr/info/dataroom_view.aspx?bid=209. Paterniti, S., Verdier-Taillefer, M. H., Dufouil, C., \& Alpérovitch, A. (2002). Depressive symptoms and cognitive decline in elderly people: longitudinal study. The British Journal of Psychiatry, 181(5), 406-410.

Pfeiffer, E. (1975). A short portable mental status questionnaire for the assessment of organic brain deficit in elderly patients. Journal of the American 
Geriatrics Society, 23(10), 433-441.

Radloff, L. S. (1977). The CES-D scale: a self-report depression scale for research in the general population. Applied Psychological Measurement, 1(3), 385-401.

Raudenbush, S. W., \& Bryk, A. S. (2002). Hierarchical linear models: applications and data analysis methods (Vol. 1). Thousand Oaks, CA: Sage Publications, Inc.

Seeman, T. E., Lusignolo, T. M., Albert, M., \& Berkman, L. (2001). Social relationships, social support, and patterns of cognitive aging in healthy, highfunctioning older adults: MacArthur studies of successful aging. Health Psychology, 20(4), 243-255.

Seeman, T. E., Miller-Martinez, D. M., Stein Merkin, S., Lachman, M. E., Tun, P. A., \& Karlamangla, A. S. (2011). Histories of social engagement and adult cognition: midlife in the US study. Journals of Gerontology Series B: Psychological Sciences and Social Sciences, 66(suppl_1), i141-i152.

Seo, S. O., \& So, A. Y. (2016). Depression and cognitive function of the community-dwelling elderly. Journal of Korean Academy of Community Health Nursing, 27(1), 1-8.

Sloane, P. D., Zimmerman, S., Suchindran, C., Reed, P., Wang, L., Boustani, M., \& Sudha, S. (2002). The public health impact of Alzheimer's disease, 2000-2050: potential implication of treatment advances. Annual Review of Public Health, 23(1), 213-231.

Steverink, N., Westerhof, G. J., Bode, C., \& Dittmann-Kohli, F. (2001). The personal experience of aging, individual resources, and subjective well-being. The Journals of Gerontology: Series B, Psychological Sciences and Social Sciences, 56(6), 364-373.

Sung, J. E., \& Kwag, E. J. (2012). Age-related verb naming abilities depending on the argument structures. Korean Journal of Communication \& Disorders, $17(4), 550-564$.

Tucker-Drob, E. M., Johnson, K. E., \& Jones, R. N. (2009). The cognitive reserve hypothesis: a longitudinal examination of age-associated declines in reasoning and processing speed. Developmental Psychology, 45(2), 431-446.
Valech, N., Tort-Merino, A., Coll-Padrós, N., Olives, J., Leon, M., Rami, L., \& Molinuevo, J. L. (2018). Executive and language subjective cognitive decline complaints discriminate preclinical Alzheimer's disease from normal aging. Journal of Alzheimer's Disease, 61(2), 689-703.

Van Dijk, K. R., Van Gerven, P. W., Van Boxtel, M. P., Van der Elst, W., \& Jolles, J. (2008). No protective effects of education during normal cognitive aging: results from the 6-year follow-up of the Maastricht Aging Study. Psychology and Aging, 23(1), 119-130.

Wilson, R. S., Beckett, L. A., Barnes, L. L., Schneider, J. A., Bach, J., Evans, D. A., \& Bennett, D. A. (2002). Individual differences in rates of change in cognitive abilities of older persons. Psychology and Aging, 17(2), 179.

Won, J. S., \& Kim, J. H. (2003). Influencing factors on cognitive function and depression in elderly. Journal of Korean Academy of Psychiatric Mental Health Nursing, 12(2), 148-154.

Yang, S., Jeong, K., \& Choi, J. S. (2017). Effects of social activities on cognitive function by gender difference among older adults: a nine-year longitudinal analysis in South Korea. Korean Journal of the Korean Gerontological Social Welfare, 72(3), 225-250.

Ybarra, O., Burnstein, E., Winkielman, P., Keller, M., Manis, M., Chan, E., \& Rodriguez, J. (2008). Mental exercising through simple socializing: social interaction promotes general cognitive functioning. Personality and Social Psychology Bulletin, 34(2), 248-259.

Zahodne, L. B., Glymour, M. M., Sparks, C., Bontempo, D., Dixon, R. A., MacDonald, S. W., \& Manly, J. J. (2011). Education does not slow cognitive decline with aging: 12-year evidence from the Victoria Longitudinal Study. Journal of the International Neuropsychological Society, 17(6), 10391046.

Zaninotto, P., Batty, G. D., Allerhand, M., \& Deary, I. J. (2018). Cognitive function trajectories and their determinants in older people: 8 years of followup in the English longitudinal study of ageing. Journal of Epidemiology and Community Health, 72(8), 685-694. 


\section{국문초록}

\section{다층성장모형 분석을 활용한 노년층의 인지능력의 종단적 변화와 영향 요인 분석} 조은하 · 성지은 · 이영미

이화여자대학교 대학원 언어병리학과

배경 및 목적: 본 연구는 시간 흐름에 따른 노년층의 인지기능의 변화를 살펴보고, 사회인구학적 요인, 신체적 - 정신적인 건강상태 요 인, 청력 요인, 사회적인 접촉 요인과 같은 다차원적인 요인들이 노년층의 인지기능 변화에 미치는 영향을 살펴보고자 하였다. 방법: 고 령화연구패널조사(KLoSA) 자료를 활용하였으며, 2006년부터 2018년까지의 7번에 걸쳐 반복 측정된 만 60세 이상 노년층 992명의 자 료를 분석대상으로 하여 다층성장모형 분석을 실시하였다. 결과: 첫째, 노년층의 인지기능은 시간의 흐름에 따라 선형적으로 감소하는 것으로 나타났다. 둘째, 인지기능의 초기치는 연령이 높을수록, 교육수준이 낮을수록, 경제상태가 나쁠수록 인지기능이 낮게 나타났 으며, 인지기능의 변화율은 교육수준이 높을수록 크게 나타났다. 셋째, 각 시점에서 우울수준이 높을수록, 주관적 청력상태가 나쁠수 록 인지기능이 낮은 것으로 나타났으며, 이러한 우울수준과 주관적 청력상태의 영향력은 시간의 흐름에 따라 감소하는 것으로 나타났 다. 논의 및 결론: 교육수준이 낮을수록, 우울수준이 높을수록, 주관적 청력상태가 나쁠수록 인지기능 감퇴를 경험할 가능성이 높으 며, 우울증상과 청력저하의 발생 초기에 인지기능 감퇴가 크게 나타나므로 인지기능 감퇴를 예방하기 위해 우울증상과 청력저하를 조 기에 선별하고 적절한 중재를 실시할 필요가 있겠다.

핵심어: 고령화연구패널조사, 다층성장모형, 노화, 인지기능, 주관적 청력저하

이 연구는 2021학년도 이화여자대학교 교내연구비 지원에 의한 연구임.

\section{참고문헌}

강상진 (2016). 다층모형. 서울: 학지사.

강연욱 (2006). K-MMSE (Korean-Mini Mental State Examination)의 노인 규준 연구. 한국심리학회지: 일반, 25(2), 1-12.

권영숙, 백경신 (2014). 일 지역사회 노인의 인지기능저하 요인. 디지털융복합연구, 12(2), 587-594.

김은주 (2010). 재가노인의 인지기능장애에 영향을 미치는 요인. 동서간호학연구지, 16(2), 122-130.

김진원, 박광호, 박휴경 (2020). 잠재성장모형을 적용한 노인의 인지기능에 영향을 미치는 운동관련 요인 종단분석. 한국스포츠사회학회지, 33(3),

$1-20$.

김호영 (2015). 노년기 사회적 삶과 인지기능 한국심리학회지: 일반, 34(1), 225-251.

김희정, 김보혜, 김옥수 (2011). 노인의 시력 및 청력 저하가 우울 및 인지기능에 미치는 영향: 2008 년 고령화연구패널조사. 성인간호학회지, 23(6),

584-594.

백옥미 (2015). 노년기 인지기능 변화궤적과 관련 요인: 잠재성장모형의 적용. 지역과 세계, 39(3), 79-103.

서성옥, 소애영 (2016). 지역사회노인의 우울과 인지기능. 지역사회간호학회지, 27(1), 1-8.

성지은, 곽은정 (2012). 연령 및 동사 논항 구조에 따른 애니메이션을 활용한 동사 이름대기 과제 수행력 차이. 언어청각장애연구, 17(4), 550-564.

양승민, 정규형, 최재성 (2017). 노인의 성별차이에 따른 사회활동이 인지기능에 미치는 영향: 한국에서 9 년간의 종단분석. 노인복지연구, $72(3), 225-$

250.

원정숙, 김정화 (2003). 노인의 인지기능과 우울에 영향을 미치는 요인. 정신간호학회지, 12(2), 148-154.

이성은 (2014). 노인의 악력과 인지기능의 관계-규칙적 운동의 조절효과를 중심으로. 한국지역사회생활과학회지, 25(1), 29-37.

이성은 (2016). 청력저하 노인의 인지기능에 영향을 미치는 요인. 언어치료연구, 25(4), 263-272.

이수정 (2018). 장노년층에서 난청과 인지기능 간의 관련성에 대한 메타분석. Communication Sciences \& Disorders, 23(2), 378-391. 
이영미, 박성일 (2021). 우리가 모르는 난청. 서울: 학지사.

이영미, 박성일, 이수정 (2020). 난청 노인의 주관적 청각장애지수에 영향을 미치는 변수 탐색. Communication Sciences \& Disorders, 25(1), 152-155. 이윤환, 나덕렬, 정해관, 홍창형, 백종환, 김진희, ... 김윤구 (2009). 치매예방을 위한 생활습관. 노인병, 13(2), 61-68.

이현주, 강상경 (2011). 노년기 인지기능의 성별 및 연령 차이. 정신건강과 사회복지, 37, 255-278.

이혜원, 김선경, 이고은, 정유진, 박지윤 (2012). 연령에 따른 인지 변화양상. 한국심리학회지: 인지 및 생물, 24(2), 127-148.

전겸구, 최상진, 양병창 (2001). 통합적 한국판 CES-D 개발. 한국심리학회지: 건강, 6(1), 59-76.

전해숙 (2013). 노인 인지문제 개선 예측요인에 대한 탐색적 연구: 한국고령자패널데이터 (KLoSA)를 이용하여. 보건사회연구, 33(2), 461-488.

중앙치매센터 (2019). 대한민국 치매현황. 서울: 중앙치매센터.

최서경, 성지은 (2019). 시선추적을 활용한 청년층과 노년층의 작업기억의 저장 및 처리기능 연구. Communication Sciences \& Disorders, 24(1), 205-

219.

최수진, 성지은, 정지향 (2020). 경도인지장애군과 정상 노년층의 명사 및 동사 유형에 따른 생성이름대기 수행력 비교. Communication Sciences \&

Disorders, 25(1), 50-62.

한지혁 (2018). 주관적 난청과 인지기능의 관계: 한국 고령화 연구패널 조사. 연세대학교대학원 박사학위논문.

황종남, 권순만 (2009). 중, 고령자의 사회활동 참여와 인지기능과의 관계. 한국노년학, 29(3), 971-986.

\section{ORCID}

조은하(제1저자, 대학원생 https://orcid.org/0000-0003-2472-5690); 성지은(공동저자, 교수 https://orcid.org/0000-0002-1734-0058);

이영미(교신저자, 교수 https://orcid.org/0000-0003-1809-5944) 